\title{
ON THE HISTORICAL EVOLUTION OF SCHOOLS IN AFRICAN PHILOSOPHY
}

Francis Ogunmodede,

Department Of Philosophy,

Seminary Of All Saints,

Ekpoma, 31001,

Edo State, Nigeria.

\section{INTRODUCTION}

Since William E. B. Dubois ${ }^{1}$ wrote The Negro in 1915 , Black Folk: Then and Now in 1939, as well as The World and Africa in 1946, scientific facts of the Leakeys and others ${ }^{2}$ have demonstrated that Africa is the actual cradle of Homo sapiens. According to Cheikh Anta Diop, (1923-1986), the foremost Senegalese Africanist, the Nile Valley of Egypt, not Greece, was the cradle of Philosophy, and other human sciences, culture and civilization. His first of ten theses which were postulated in his doctoral work at the University of Paris, Sorbonne, Paris in 1954 went thus: "Our investigations have convinced us that the West has not been calm enough and objective enough to teach us our history correctly, without crude falsifications. Today, what interests me most is to see the formation of teams, not of passive readers, but of honest, bold research workers, allergic to complacency and busy substantiating and exploring our ideas expressed in our work, such as:

1. Ancient Egypt was a Negro civilization. The history of Black Africa will remain suspended in air and cannot be written correctly until African historians dare to connect it with the history of Egypt. In particular, the study of languages, institutions, and so forth, cannot be treated properly; in a word, it will be impossible to build African humanities, a body of African human sciences, so long as that relationship does not appear legitimate. The African historian who evades the problem of Egypt is neither modest nor objective, nor unruffled; he is ignorant, cowardly, and neurotic. Imagine, if you can, the uncomfortable position of a western historian who was to write the history of Europe without referring to Greco-Latin Antiquity and try to pass that off as a scientific approach. 
The ancient Egyptians were Negroes. The moral fruit of their civilization is to be counted among the assets of the Black world. Instead of presenting itself to history as an insolvent debtor, that Black world is the very initiator of the "western" civilization flaunted before our eyes today. Pythagorean mathematics, the theory of the four elements of Thales of Miletus, Epicurean materialism, Platonic idealism, Judaism, Islam, and modern science are rooted in Egyptian cosmology and science." ${ }^{\prime 3}$

Verily, the Nile Valley in Egypt was the matrix of Philosophy. And just as we say that no Nile, no Egypt, so we can say today, too, No Ancient Egyptian Philosophy, no African Philosophy in line with the $1^{\text {st }}$ thesis of Diop. But, we must stretch the syllogism further more by stating, also; No Ancient African Philosophy, no other Philosophies like Oriental and Western Philosophies. Indeed, the reality on the ground, is that we have Ancient Egyptian Philosophy, and its basic tenets which have been adopted in the Western Philosophies, for example, that have emerged later on in history according to George James, ${ }^{4}$ Henry Olela ${ }^{5}$, Joseph Eneh, ${ }^{6}$ Molefi Kete Asante and Onyewuenyi. ${ }^{\mathrm{s}}$

Now, African Philosophy articulates the African experience of reality. It proffers solutions to the basic questions which are asked and issues which are raised by the African in his milieu. Since African Philosophy has existed from ancient times, it would be expected that it would have diverse shades of opinion and view points, schools of thought and traditions about God, man, society and the world at large.

A school of thought in philosophical speculation can be described as the critical viewpoint or doctrine held by a certain group of philosophers or a centre of learning on a particular issue, or, on the nature of reality in general. Also, its system of ideas can be named after its founder or town of location e.t.c. Naturally, these schools of thought and traditions have emerged in the past. Some of these including new ones exist in present, just as much as new ones would emerge in the future. What can best be done is to give the principal schools of philosophical thought, which we can identify.

There have been some attempts made at identifying and describing the schools of African philosophy. Unfortunately, these efforts have been limited to the contemporary period of African philosophy. An example of this inadequate analysis of schools of African philosophy is the publication of $G$. 
E. Azenabor titled, Understanding the Problem of African Philosophy, (1998), which gave a comprehensive historical analysis of schools of African philosophy today but ignores those of the past as if no one existed then. It is our aim to correct this omission in this work especially as it has given weight to those who think that African Philosophy started only recently" "Our analysis shai begin with the schools of philosophical thought in ancient times in Africa and, then, move on to the medieval, modern and contemporary schools.

\section{ANCIENT SCHOOLS OF AFRTCAN PHILOSOPHY}

\section{SCHOOLS IN EARLIEST TIMES: ORTGINAL WORD FOR "PHILOSOPHY" AMONG THE ANCIENT EGYPTIANS}

Before analysing the doctrines of the ancient Egyptian schools of "philosophy", let us begin with the original word and meaning of "philosophy" among the ancient Egyptians thinkers and philosophers. The word used by the ancient Egyptians for philosophy was "Saboyet"12 which means "Wisdom" or "Instructions", or "Teachings". Thus, we had "The Teachings of Ptah-Hotep", which is the oldest and complete political treatise that has survived the vicissitudes of antiquity and is still available to us.

Now for the ancient Kemites, or, Egyptians, "Seboyet" has a double meaning and sense, namely, "theoretica/wisdom" and "practical wisdom". Theoretical wisdom means knowledge and truth while "Practical wisdorn" means Justice, Rectitude, Virtue and Perfection. At this early stage of man, when he still very much cherished his intrinsic relationship with his Creator, "human wisdom" was known to come from "Divine wisdom". Hence, Seboyet. was not just knowledge for its sake, but for a purpose, namely, MAAT or the act of seeking perfection in life in order to be in close union and communion with God, the divine Master.

The intellectual, moral and spiritual nature of Wisdom was already properly noted when the early Greek philosophers came into the scene afterwards. Pythagoras who had been instructed for twenty-two years in Egypt, for instance, called this process of acquiring perfection, "Philosophy", (the Love of Wisdom), when he returned to Greece and started his own community. 


\section{ANCIENT EGYPTIANS MYSTERY SCHOOLS}

More than before, we now have incontrovertible evidence to show that Philosophy, the Queen of the sciences existed as a tradition according to Lancinay Keita ${ }^{13}$. Also, according to H.G. Hilliard ${ }^{14}$, it was taught formally in ancient times in Africa. Besides, more facts have been brought in by Martin Bernal to sustain that the Nile Valley religious temples in Egypt were the earliest centres of philosophy and philosophical schools in the world. ${ }^{15}$ This is a fact, which was stated by Isaac Newton and by the Greek philosophers, themselves. ${ }^{6}$ Now, while the Ancient Egyptian schools were the first schools of Philosophy in history, the Greeks and others have borrowed some basic elements of Egyptian schools of Philosophy and added their own contributions to them. ${ }^{17}$

Now, the earliest Egyptian philosophical schools were known as Egyptians mystery systems, which were taught at centers or temples of religious worship at:

(i) Memphis

(ii) Hermopolis

(iii) Heliopolis

(iv) Thebes

(v) Tell el Amarna

(vi) Avaris

The earliest Egyptian schools of philosophy were not called after any individual philosophers as it was to be the practice after the philosophers of Greek origin had gone to learn wisdom from the temples in Egypt and returned to their own native land to establish similar ones. Rather the schools were named after the Egyptian cities and towns where the schools or mystery schools were located or after the Temples in honour of the god that is worshipped in the city. Thus, it was usual to call a school of thought or, philosophy, Memphis Thought System or Memphis Mystery school after

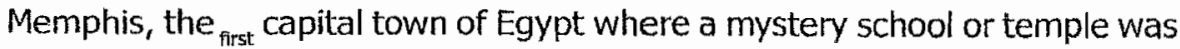
first located. 


\section{DOCTRINES}

The early Egyptian philosophers were very keen observers of nature (moon and stars), men and God. They reflected deeply, too, on the existing relationship amongst the various elements and segments of reality. Consequently, these schools of thought postulated the earliest of philosophical thoughts and doctrines known by man. At first, philosophical thoughts were couched in mythology and mysticism, but later, they developed as logicoontological thought system of a holistic or empirico-metaphysical genre. The schools had, also, a defined cosmology, anthropology, theology and ethics. These philosophical disciplines were taught in unison with other disciplines like mathematics, astronomy, medicine and literature, etc.

Of these six famous schools, the School at Memphis was the oldest (4500 B.C) and has the enviable record of developing most of the basic doctrines of Philosophy and Theology, which the other Egyptian Schools of thought held and taught to their students and which were in turn transmitted to generations after them, and in, fact accepted as sound philosophical doctrines today. Some of these essential philosophical doctrines, which we have in mind, are

as follow:

1. Creation ex nihilo

2. Four basic elements with water being the first followed by air, fire and earth.

3. Motion and changes

4. Dialectics and the Law of opposition

5. The Uncaused Cause or Unmoved Mover.

6. Immortality of the Soul (Anthropology and theology)

7. Unitary and hierarchical State (Politics). 
But, when it comes to the doctrine of Monotheism or One and Supreme God in ancient times, the School of Tell el Armana was unique and revolutionary with its doctrine of Atenism postulated by the founder and Pharaoh Akhenaton in $1.303 \mathrm{~B} . \mathrm{C}$.

Inspite of the significant role that the schools of Memphis, Heliopolis, Hermopolis, Thebes, and Tell el Armana and Avaris have played in bringing philosophical doctrines to limelight, we must not forget that they were not the only centers or temples existing in ancient Egypt. There were other philosophical and learning centers as well. For example, we have in the following: cities or towns, these schools, or, temples

The Temple of Bast at Bubastis.

The Sakkara complex.

- The Labyrinth at Fayyum.

- $\quad$ The Temple of Hatheru at Dendera.

- The Osirieon at Abydos.

- The Temple of Amen at Karnak

- The Temple of Heru

- The Temple of Khnum at Aswan

- $\quad$ The Oracie of Amen at Siwa Oasis.

- The Temple of Auset at Philae

Numerous, also, were the students who attended these schools in ancient Egypt. They were about 80,000 students at Ipet-Isut Temple for instance, and wanted different grades of divine knowiedge. The ancient Egyptian Mystery System consisted of three classes of students; a) the mortals or new initiates who were under probatori b) the intelligences; who had attained the inner vision by purification of their inordinate ambitions for the purpose of mental orientation c) Creatori; this is the highest class which consists of those who 
have been properly attuned spiritually. They have become perfect beings that would commune with the 'gods' and are called Sons of light. Eneh thinks that the spiritual advancement of the Creators...must have given birth to the Egyptian white brotherhood known as the Essenes or the Egyptian white Brotherhood. ${ }^{18}$ According to A.G Hillard's work, our tripartite grading of B.A., M.A, and Ph.D came from this Egyptian educational grading system ${ }^{19}$, also, there were as many as 80,000 students at all levels of learning at Ipet-Isut or Karnak temple in Arabic alone seeking wisdom. Molefi Asante gives the explanation for the phenomenon of high level of enlightenment among the ancient Egyptian society.

The ancient Africans of the Nile Valley

believed that knowledge was the way to

life and the way to life led directly to the

divine. Inner knowledge came from

the search for divine and wisdom was the result of inner knowledge. ${ }^{20}$

To conclude the analysis of the mystery schools or philosophical schools in the Earliest Ancient Period of Egypt, we must add that knowledge was then seen as wholisitic and integral. However, we cannot talk of the students and curriculum while we leave out their teachers and philosophers who taught them. These will include the following personalities:

\section{Imhotep, $(2700 B C)^{2 . t}$}

Imhotep was the vizier of Pharaoh Djoser of the $3^{\text {rd }}$ Dynasty (29802900 B.C). It was the view of Molefi K. Asante that Imhotep, instead of PtahHotep, is the first human philosopher to be recorded in history. He is regarded, also, as the father of natural science, medicine, architecture and politics. The doctrine of immortality of the soul could be traced down to him. His works are not extant and his teachings are brought down to us through historical references in other works.

\section{Ptah-Hotep (2414 B.C $)^{22}$}

This was a vizier of the $5^{\text {th }}$ Dynasty. He is regarded to be the greatest moral philosopher of ancient times. The instruction of Ptah-Hotep is a classic in ethico-political philosophy and it is still available. 


\section{5agemm the sage $\left(2300 B_{x} C\right)^{23}$}

He was a priest and vizier of Snefru in the $6^{\text {th }}$ Dynasty. ${ }^{4}$ He must have served in the reign of Huni too. He is hoted for the doctrine that man should perform right deeds for its sake and for God rather than for personal interests.

\section{Mhumanu story $(2010 B C)^{24}$}

The doctrine of this peasant philosopher is that good will always triumph over evil and that the law permits the weak and poor to seek redress and justice against the rich and oppressive class in society.

\section{Swernemfat $(1991 B C)^{25}$}

Amenemhat was the first Egyptian philosopher of cynicism. He taught that a leader must be careful of those nearest to him or her.

\section{Sehotepitsre $(1991 B C)^{26}$}

He is called the faithful and loyalist philosopher by scholars Sehotepibre taught loyalty and allegiance to the king and other constituted authorities and often used himself as an example to others.

\section{Merikare (1990BC)}

Merikare is called the philosopher of communication. He wrote on the value of good speeches in the public and using common sense in human relationship.

\section{Amenhotep, Son of Hapu $(1400 B C)^{2 s}$}

Amenhotep was the most revered of the ancient Kemetic philosophers; he was deified after Imhotep. This was because of his knowledge, diligence in teaching Maat and being good an architect for many kings. 


\section{Duauf $(13408 \mathrm{C})^{29}$}

He can be regarded as the philosopher who taught the arts of good living in society. He urged youth to read good books so as to train the mino and "learn the secrets of hidden things."

\section{Akhenatom $(13006 \mathrm{C})^{30}$}

This is the father of monotheism in the ancient world. He propounded the revolutionary doctrine of the One and Supreme God called Aten represented by the sum disc. This Pharaoh changed his name from Amenhotep III to Akhenaton, which means "Aten is satisfied", and moved the capital from Thebes to Tel-el-Armana. Here, he abolished the class and the duty of priests existing in the new royal temple and made himself the sole Priest and mediator between Aten and the people. This act was unique in the religious history of the Egyptians. But, it was done because of the preference of the priests for the old mode of worship (polytheism) and dislike for the newly introduced religious worship (monotheism), which did not enhance their economic interest and status in the state.

Akhenaton was as well a pacifist, poet and a realist in aesthetics at Tel-el Amarna. For all this, he was very much hated by the conservative priests and nobles at Thebes and Tel-el-Amarna so that when he died, his body was possibly bumt so that it was never found again and his name was removed from the archives as a religious rebel.

\section{Amenomope (1290 BC $)^{31}$}

He propounded the philosophy of manners, etiquette, and success in life. We learn these properly only through the use of proverbs. He taught, also, that the proper appreciation of the ancestors was the basis of society, since it was they who had established proverbs as the source of wisdom. 


\section{THE LATTER PERIOD}

\section{(a) ECCLECTIC SCHOOL OF ALEXANDRIA (20 B.C)}

Before, only few Greeks and other aliens were coming into Egypt after the Hyksos had been expelled. But, after the forces of Alexander had conquered Egypt in 332BC, there was a massive influx of students of Greek origin and Asiatic aliens in Alexandria and other Egyptian cities. ${ }^{32}$ These came to learn of the wisdom of the gods from the priests in their religious temples cum schools. Aristotle, also, shifted his own base and directed the students of his Lyceum to come down to study in Egypt now under the control of his former pupil, Alexander the Great. ${ }^{33}$ With the conquest of Egypt by the Romans in 48BC, a new Greeco-Roman culture, called Hellenism, gradually evolved from the ideas taught in the Mystery Schools of the Egyptians. This took place precisely in Alexandria, the new name by Alexander the Great given to Thebes, the capital of Egypt.

New philosophical schools, also, evolved, e.g. the Greek Pythagoreansim, Socratism, Platonism, Aristotelianism and several other Oriental schools of thought. The Ecclectic School appeared, also, in Alexandria Egypt towards the end of the millennium Before Christ, approximately $20 \mathrm{BC}$. It is a synthesis of the truths in various philosophical thoughts and religious movements of the time. The school was actually known as Selective Choice School: and had Philo as a member. Together with the Gnostic movements, also, in Egypt, it paved the way for neoPlatonism. ${ }^{34}$

\section{(b) NEO-PLATONISM ( $2^{\text {nd }}$ Century BC $-4^{\text {th }}$ Century A.D)}

This school is the last of the great ancient philosophical systems, and greatly influenced Christian thinkers like Origen and Augustine comparable with Platonism and Aristitelianism, it was first proposed by Amonius Saccas (175-242 A.D). But it was his st.udent, Plotinus, the Egyptian, who first expounded it as a philosophical school in Alexandria. Like the eclectic school it combined together pythagoreanism, Platonism, Aristotelianism, stoicism, oriental religious elements. Hypatia the first renowned woman philosopher headed this school later on but was killed by a Christian mob led by St. Cyril in 415AD. ${ }^{35}$ 


\section{(c) HERMETICISM AND GNOSTICISM (2 $2^{\text {nd }}-3^{\text {rd }}$ Century A.D)}

Hermeticism revolved round Hermes Trismengistus (Theuth and Hercules) a mythical figure or god. Hermeticism was seen as the essence and embodiment of Egyptian wisdom and had impact on European science in the age of the Renaissance. Hermetic Corpus is a collection of 42 works and dicta of various Egyptian and Greek authors and appeared in Egypt in $2^{\text {nd }}$ Century A. D. ${ }^{36}$

\section{(d) CATECHETICAL SCHOOL, OR, ALEXANDRIAN ACADEMY OF PHILOSOPHY AND THEOLOGY (50-415AD)}

All the Egyptian schools mentioned so far were pagan in nature. But, after Christianity came to Egypt, very soon after Pentecost in 50AD, Alexandria in Egypt became also the $1^{\text {st }}$ center of Christian studies in the ancient Hellenistic world. It was in African and particularly in Egypt's Alexandria, that the new religions of Christianity began to formulate and develop its theoretical doctrines. So just as the Egyptian school of Memphis, Heliopolis, Thebes, Tel el Amarna etc. produced the earliest pagan thinkers, so, too, Christian Philosophy and Theology were to start in Egypt. It followed, also, that the first of the greatest Christian philosophers and theologians were to come from Egypt in Africa. The most renowned thinkers of this Catechetical School were Clement, Origen, St Cyril. They postulated the doctrines of the Blessed Trinity, Hypostatic Union in Christ as God and man, and Mary as the Mother of God ( $\theta \omega$ ?????? ${ }^{37}$

\section{SCHOOLS OF AFRICAN -PHILOSOPHY IN THE MEDIEVAL PERIOD}

\section{(a) SCHOOL OF CARTHAGE}

Carthage, near Tunisia, was famous for the black Hannibal the great who drove out the Romans and went thereafter to attack Rome, the capital of the then known world (Punic wars) ${ }^{38}$. He was defeated and Carthage destroyed in 146BC By the Romans. Carthage was also renowned as a center of learning for philosophy and Theology. Tertullian and St Cyprian were two of her illustrious scholars who contributed to Christian philosophy and 
theological doctrines St Augustine taught rhetorics there as well in the fourth century AD. However it was captured in 697AD and islamized during the expansionist movement of the Muslims. 39

\section{(b) AXUM SCHOOL OF PHILOSOPHY IN ETHIOPIA}

Ethiopia is another country whose thinkers have contributed a lot to the oral and written philosophico-theological speculations in the recent period of Africa. To be mentioned is the school of Aksum in the Northern kingdom. The school was alive in two periods. It existed between $4^{\text {th }}$ and $7^{\text {th }}$ centuries A. D. in its first period. Its philosophers were the fundamentalist Skandes and the rationalist Zara Yacob born in 1599 and whose work, Hatata reflected on the effect of war. According to Claude Sumner ZA a a Yacob was actually the father of modern philosophy and not, Rene Descartes, of France. ${ }^{40}$

\section{(c) JENNE AND SANKORE SCHOOLS IN TIMBUKTU (MALI)}

\section{AD}

In Medieval period, Sankore University existed in Mali. This was an Islamic center for the learning of letters, law, medicines, astronomy, philosophy, and theology. Islamic scholars came here from Spain, Morocco, Persia, Egypt, to exchange and develop ideas with fellow erudite African scholars in the $14^{\text {th }}$ century. In recognition of this University, the UNESCO has established a research institute in honour of Baba Ahmed, one of its best scholars. This is also, an attempt to collect all the relevant documents a great number of which are still to be found in the libraries of North African, Europe, the Middle East and Armenia, and even in the homes of leading African citizens and scholars in the Sahel. ${ }^{41}$

\section{SCHOOLS OF CONTEMPORARY AFRICAN PHILOSOPHY.}

After identifying the main schools of thought and centers of learning that existed in the African past, let us turn to those that have emerged in the post colonial and contemporary eras of Africa. Several schools of African philosophy have been delineated by various African philosophers. Credit must be given to Chapter One of Azenabor's work, Understanding the Problems of 
African Philosophy, (1998) ${ }^{42}$ which has listed out most of them, beginning with Wiredu.

J. E. Wiredu in On An African Orientation in Philosophy (1981) ${ }^{43}$ identified two schools of thought or approaches: the Universalist and the Nationalist. P. O. Bodunrin mentioned two, also, in Trends and Perspectives In African Philosophy (1985); the traditionalist and the modernist. ${ }^{44}$ Olusegun Oladipo in The Idea of African Philosophy (1992) ${ }^{45}$ identified two as well: the analytic and the traditionalist. K. Anyanwu described two schools, the Atomist (analytic) and the holistic (traditionalist) ${ }^{46}$. G. Sogolo, in Foundation of African Philosophy: A definitive Analysis of Conceptual Issues in African Thought, gave two schools backward looking traditionalist approaches and forward looking progressive and analytic approach ${ }^{47}$ Odera Oruka's four schools of thought go like this in his book Trends in Contemporary African Philosophy (1990) ${ }^{48}$ Ethno-philosophy, Philosophic Sagacity or Sage philosophy Nationalist ideological philosophy, Professional philosophy. Later on in his Sage Philosophy, (1991) ${ }^{49}$, Oruka identified five schools of (philosophyEthnographical), the rationalist, the historical, the hermeneutical and the literary artistic schools of thought.

Jay M. Von Hook in his article, "African Philosophy Its Quest For Identity" recognised, also, two schools: the universalist and the particularists. ${ }^{50}$ A. F. Uduigwomen in Footmarks in African Philosophy, (1995) ${ }^{51}$ identified three schools; the universalist, the particularist and the ecclectic schools. M. F. Dukor in his book, Theistic Humanism ${ }^{52}$ has two schools: the monist and the liberal schools. 
C. S. Momoh has three schools ${ }^{53}$-- Theological school, African logical neo-positive school, Purist school,

Azenabor has five schools ${ }^{54}$ - Theological school, African logical neopositive school, Purist school, African ideological school, Marxist orientation in African philosophy

Oguogho and Nwala have a classification of six. T. U. Nwala in the introduction to his edited work Amo's Place In Intellectual History, (1990)55 has identified the six schools of African Philosophy as follow; (a) ethnophilosophy (b) philosophic sagacity (c) nationalist-ideological philosophy (d) egypto-philosophy (f) philosophical materialism. But, it was in the critical review of The Great Debate On African Philosophy (1970-1990), 1992 that Nwala espoused these various schools of thought. ${ }^{56}$

From the above we can identify seven schools of thought and these are as follows:
(1) Ethno philosophy
(2) African Philosophical Sagacity
(3) Analytico-positivism

(4) Nationalist ideologico-political school 
(5) African Marxists

(6) Christian realists

(7) Egyptologism

(8) Afrocentricism

The affinity and affiliation of a philosopher to a particular school depends on his exposure and experience. These schools complement one another in African philosophy. We shall now describe and evaluate them as follows:

\section{Ethno-philosophical school:}

Ethno-philosophy is a brand of philosophy, which uses the methods, and principles of ethnographers, or anthropologists in its investigation. It is a collection and synthesis of the world-views, and common beliefs of people living in the primitive society. The Ethno-graphical method was adopted by expatriate Christian missionaries like Fr. Tempels, Alexis Kagame, John Mbiti, Robin Horton, E. A. Ruch and K. C. Anyanwu.

\section{Critique:}

This is a quasi or implicit philosophy. According to Odera Oruka in his books Trends in Contemporary African Philosophy, Ethno philosophy as a collective view-point is basically the religious experience of everyone rather than the explicit thought or rational argument of any individual in particular. Even in the so-called primitive and ancient societies that ethno- philosophy attempts to describe, there were still evidences of individuals who were intellectuals and made critical reflection of their communal world-view using their power of reason, rather than the celebrated beliefs. These individuals like Ogothomeli have produced philosophical systems worthy of study. ${ }^{57}$

\section{Philosophical Sagacity:}

According to Oruka, Philosophical Sagacity is otherwise known as Sage philosophy. It is the philosophical wisdom of sages. A sage is usually an elderly, quiet, knowledgeable and experienced person in the preliterate community. The sage's repertoire of knowledge is vast indeed and it is metaphysical and historical in contents. Dialogue or oral discussion forms the only mode of transmission of knowledge which is very much dependent 
on the memory of the sage. Scholars who belong to this school are Odera Oruka, J. O. Sodipo, M. A. Makinde, B. Hallen, etc.

\section{Critique:}

This is a reaction to the Ethnographic school which tends to depict and pejurate African Philosophy as only a communal cradle which abhors any individual and critical value. Besides, sages are not exclusive peculiarity of the primitive African society, but are to be found in all societies where oral tradition is a cultural heritage, Thus, Socrates (Greek), Jesus Christ (Jews) and Ogothomeli (Dogon) were the sages of their ages and societies.

\section{The Analytic Positive School}

According to C. S. Momoh, in The Substance of African Philosophy, (1989) this school is constituted by those philosophers who are either not excited about the claims and content of African philosophy and who consequently query them, or, by those philosophers who absolutely denied the existence of African philosophy..$^{58}$

Protagonists of this school of thought are Hountondji, P. O. Bodurin, early K. Wiredu, Horton, Henri Mourier and early Oruka. The basic propositions of the analytico-positivist school can be summarized thus:

(a) Philosophy is an individual and written activity and not a collective and oral tradition as in ethno philosophy

(b) It is a critical, objective and rigorous discussion of individual ideas and concepts and problems of universal nature and character.

(c) African philosophy should be modeled after the modern western category and canon of discourse. 
(d) African philosophers today should de-emphasize national., cultura or linguistic factors in philosophy and emphasize insteac universally valid and rationally grounded principles.

(e) African philosophy should embrace the analytico-scientific spiri and method of investigation.

\section{Critique:}

Professor Makinde ${ }^{59}$ has described the philosophers of this school of thought as Euro-African philosophers, or, as the "African Vienna circle". Aftei all, Peter Bodunrin, their chief spokesman, said that he was doing what Alfrec Ayer did in Language, Truth and Logic, namely, expounding, explaining and defending the views of this linguistic-positivist school of thought.

More serious in our critique of this school is the fact that the members of this school are slaves of their western education, ideology and background. Even though they revere science, they are merely dogmatic and ignorant of development in modern science, which now coexists with spiritual and metaphysical entities because of the realization of the limits of science. Firstly, science itself is based on metaphysical principles. For instance the law of causality. Secondly, the greatest revolution about human knowledge today is the recognition that it comes not from objective science, but from human experience. In emphasizing the analytic method, the logical-positive school has not taken sufficient notice of the history of philosophy. 
Philosophy has also been non-analytical, non-systematic, intuitive, synthetic, and narrative at a stage of its development and growth. Indeed current French philosophy still emphasizes these aspects.

\section{(4) Nationalist-Ideological School}

This school represents the viewpoints expressed by our nationalists who fought for political and economic freedom for Africa and Africans in hotcolonial period and its aftermath. The main thrust of reasoning and preoccupation was the search for the ideal socio-economic and political system to be adopted after independence by Africans. By and large, a return of communalism as African system that will bring about development was advocated viz African humanism of Kenneth Kaunda, Neo-Welfarism of Nnamdi Azikwe and Democratic socialism of Obafemi Awolowo, and Pan-Africanism of Kwame Nkrumah.

\section{Critique}

National ideological school has to formulate African socio-political philosophies, which are still current and relevant. But, most views expressed and systems adopted were towards Marxism and socialism (East). The weakness of this African politico-economic system has been shown by the collapse of the Union of the Soviet Socialist Republic. Also, African solutions to our political problems remain ad-hoc and unscientific.

\section{Marxist school}

If the nationalist-ideological school could be said to have been brought about by the experience and reflection of politicians, the Marxist school is its by-product and offshoot. Professional African philosophers and academic scholars who in their negative response to the colonial struggle in Africa have adopted the anti-capitalist, Eastern European and particularly Marxist model in their socio-political and economic thoughts constitute this school. Some of these are theistic, some others are atheistic within the broad Marxist spectrum. 


\section{Critique}

Protagonists are Oladipo, Wiredu, Diop. Indeed it could be said that the majority of these intellectuals are, humanists-socialists in character in their ideology. But many of these intellectuals have soften their position as realities have changed, and they now advocate modified-state capitalism, and even, private enterprises. For example Nyerere's Ujamaa now admits of private entrepreneurship when it was realized that collective holdings and entrepreneur The Collapse of the Soviet Union is perhaps the greatest lesson that there is no perfect socio-economics system and that individual creativity and involvement in economics encourage and guide rather than stifle the transmission of ideas.

\section{(5) Christian Realists}

This is the school which C. S. Momoh and his disciple, G. E. Azenabor refer to as the theological school. Truly, we cannot deny the fact that, philosophy as a professional discipline and academic status as it has attained today in the African Universities ha been promoted mostly by Catholic Priests and ex-Seminarians. In any case, philosophy was born in the religious temples in Egypt. Also. The $1^{\text {st }}$ Christian and catholic center of learning began there in Alexandria. Thus, we may have a school of philosophy that could be called Christian Realism. It is "realism" because it is balanced and objective, and combines together idealistic and naturalistic elements of reality and it is "Christian realism" because of the Christian background, values and perspective of its contents and practitioners. Protagonists are for example, Okolo, Onyewuenyi, Omoregbe, Ogunmodede, etc.

\section{Critique}

This school can be said to be a sub school of the theological sc hool according to Momoh, but, what makes this school distinct is the great number of Christian philosophers in our universities and seminaries and their emphasis on the spiritual or Christosphere as the essential aspect of reality and consequently of metaphysical inquiry. 


\section{(6) Egyptologism}

This is the school of philosophy that advocates the primacy of African philosophy among all philosophies and has Egypt as the cradle of philosophy. According to me and Cheik Anta Diop, James Onyewuenyi, Chinweizu, and Asnate Molefi, etc. we cannot talk of philosophy, or, African philosophy for that matter without recourse to Egypt. Since in fact, human civilization and culture became refined and spread from there to other lands.

\section{Critique}

Some question the primacy of Egypt and still accord Greece as the foundation of philosophy or Greece as the source of Greek philosophy ${ }^{60}$. Those who do so only betray their ignorance of current historico-scientific researches and evidences. We should leave them behind in their caves as daydreamers.

\section{(7) Africanist School}

This school like the last school can be said to believe in variety of philosophies but asserts that African philosophy exists and is one out of many philosophies of mankind. This view justified by its belief in the heterogeneity of human experience, which is the source of the philosophical doctrine of the African. This school strongly considers mother tongue and African language as a basis of doing African philosophy. Protagonist of this school include Oluwole, Makinde, Anyanwu, and Ogunmodede.

\section{Critique}

It is the African logico positivists that are against their method of using African language and experience as the center-point of reflection in African philosophy. But the criticism of the logico-positivist school has already been faulted by scientific researches demonstration of the correlation between language and intelligence development ${ }^{61}$. Their criticism will remain baseless in so far as the Africanists continue to pre-occupy themselves with the emancipation and development of Africa and the African in their reflections. 


\section{CONCLUSION}

The schools that have been presented here are only another humble effort to reconstruct the history of African philosophy, especially in the difficult and remote period of Africa ${ }^{62}$. We hope it has been a worthwhile exercise.

\section{NOTES AND REFERENCES}

' William E.B. Dubois was the famous black American scholar who has writte profusely in order to project the achievements of the black race in the pas and in the present. Some of his other works are as follows: The Philadelphi Negro (1896); Suppression of the African Slave Trade to America Harvar Ph.D thesis published as Vol. I of Harvard University Historical Series, 1896 Souls of Black Folks (1903); Black Reconstruction (1935); The Autobiograph of W.E.B. Dubois 1968)

2 Louis Leakey, The Progress and Evolution of Man in Africa Oxford: Universit Press, 1961; Report to the VII Pan African Congress on Pre-History and th Study of the Quatenary Addis Ababa, 1971.

${ }^{3}$ Cheikh Anta Diop, African Origin Of Civilization Myth or Reality? Trans an edited by Mercer Cook Westport: Lawrence Hill \& Company 1974 pxiv ${ }^{4}$ George James, Stolen Legacy, Reprint. California: Julian Richardso Associates, 1985. "According to history, Pythagoras after receiving his trainin in Egypt, returned to his native island, Samos, where he established his orde for a short time, after which he migrated to Croton (540 B.C) in Souther Italy, where his order grew to enormous proportions, until his final expulsio from that country. We are also told that Thales (640 B.C) who had als received his education in Egypt, and his associates: Anaximander, an Anaximenes, were natives of Ionia in Asia Minor, which was a stronghold o the Egyption Mystery schools, which they carried on. (Sandford

's The Mediterranean World; p. 195-205). Similarly, we are told tha Xenophanes (576 B.C.), Parmenides, Zeno and Melissus were also natives o Ionia and that they migrated to Elea in Italy and established themselves an spread the teaching of the Mysteries.

In like manner we are informed that Heraclitus (530 B.C.), Empedocles Anaxagoras and Democritus were also natives of Ionia who were intereste in physics. Hence in traceing the course of the so-called Greek philosophy we find that Ionian students after obtaining their education from the Egyptiar priests returned to their native land, while some of them migrated to differen parts of Italy, where they established themselves. 
Consequently, history makes it clear that the surrounding neighbours of Egypt had also become familiear with the teachings of Egyptian Mysteries many centuries before the Athemans, who in 399 B.C. sentenced Socrates to death (Zeller's Hist. Of Phil.,112; 127;170;172) and subsequently caused Plato and Aristotle to flee, for their lives from Athens, because philosophy was something foreign and unknown to them. For this reason, we would expect either the Ionians or the Italians to excert their prior claim to philosophy, since it made contact with them long before it did with the Athenians, who were always its greated enemies, until Alexander's conquest of Egypt, which provided for Aristotle free access to the Library of Alexandria.

The Ionians and Italians made no attempt to claim the authorship of philosophy, because they were well aware that the Egyptians were the true authors. On the other hand, after the death of Aristotle, his Athenian pupils, without the authority ognized at that time as the Sopia or Wisdom of the Egyptians, which had become current and traditional in the ancient world, which compilation, because it was produced by pupils who had belonged to Aristotle's school, later history has erroneously called Greek philosophy, in spite of the fact that the the Greeks were its greated enemies and persecutors, and had persistently treated it as a foreign innovation. For this reason, the so-called Greek philosophy is stolen Egyptian philosophy, which first spread to Ionia, thence to Italy and thence to Athens. And it must be remembered that at this remote period of Greek history, i.e., Thales to Aristotle 640 B.C322 B.C., the Ionians were not Greek citizens, but at first Egyptian subjects and later Persian

subjects". Pp. 9-10.

${ }^{5}$ Henry Olela, "The African Foundations of Greek Philosophy" in R. Wright, African Philosophy An Introduction, Washington; The University Press of America 1976, pp. 55 - 70

${ }^{6}$ Joseph O Eneh, An Introduction To African Philosophy And Thought Enugu; Satellite Press Ltd "There was an Egyptian Mystery system which existed before the birth of notable Ionian/milesian and Greek thinkers known by the western thinkers as the founders of western Philosophy. The school was the first established university by the Egyptian priest - plilosophy-scholars who were versed in both religion, philosophy and natureal sciences. The mystery system became the source of lint of the physical, socio-political and intellectual disciplines. It attracted wisdom espers and scientists from Ionia/Miletias, Greece, Asia Minor and some other early Egyptian colonies. This fact explains why the Greek philosophers and scientists in the part became proud of themselves for having been educated in ancient Egypt.

7 Molefi Kete Asante: "Egypt is far older as a Civilization of thinkers than Greece. It pre-dates Greece not only in in political terms, but in age. Egypt is thousands of years older in terms of its development of science, method, theory, and philosophy. Only when this is clearly seen and understood can we understand that africa is the mother of all philosophy and that the ancient Nile valley thinkers contributed to the 
world a full body of intellectual and creative works long before Thales Anaximander, and Anaximenes of Melitus and Heraclitus of Ephesus, 0 Isocrates the Ionian came to study with them in the 6th century BC.

By the time the Greeks found Egypt, the seat of ancient wisdom and knowledge, the ancient Egyptian philosopers had been reflecting on the natur of human relationships and the meaning of life for several thousand years Indeed, there is some indication that they had imparted their thinking, certainl) in royal terms, to Crete before their explosion of Santorini. The Greeks wert mere children in comparison. Nevertheless, it is important to point out exact) what the eaarly Greeks added to the educatiom that they received from the ancient Africans in Egypt

'CfThe Egyptian Philosophers: Ancient African Voices From Imhotep Tc Akhenaten; Chicago: African American Images, 2000 pViii-ix.

${ }^{8}$ Innocent Onyewuenyi, "Moreso, Aristotle recognized the primacy of Egypt as the home of Philosophy" cfr The African Origin of Greek Philosophy. An Exercise in Afrocentrism, Nsukka: University of Nigeria Press, 1994 p. 43.Asante, Ibid., p.xiv.

${ }^{9}$ C.S. Momoh. The Funeral of Democracy Lagos: African Philosophy Projects Publications 1993, p28

${ }^{10} \mathrm{cfr}$ G.E. Azenabor, Understanding the Problem of African Philosophy Lagos: First Academy Publishers 1998 Part One pp 1-17

${ }^{11}$ C.B. Okolo, African Philosophy in this academic sense is of recent origin not much more than two decades in this part of Africa, but it is fast establishing its own intellectual tradition in Africa and among African scholars in Africar Philosophy: A Short Introduction Enugu: Cecta Nigeria Ltd, 1993 p.8. Also C.S. Momoh said: Fortunately, African philosophy has arrived because Africar philosophy has been the missing link in the long awaited arrival of the Africar - We are the ones who will chart and we have in fact started charting the direction and future of African philosophy

" in African Philosophy. Past, Present And Future (A paper presented at the International Workshop on William Amo, Department of Philosophy, University of Nigeria) June $14^{\text {th }}-18^{\text {th }}, 1997, p 1$.

12 M.K. Asante op. cit $p$ ix

13 Lancinary Keita, "It is the purpose of this paper to present evidence that a sufficiently firm philosophical tradition existed in Africa since ancient times, and that this tradition is of sufficient intellectual sophistication to warrant analysis" cfr "The African Philosophical Tradition in African Philosophy: An Introduction, Washington: The University Press of America, 1976. p35.

${ }^{14}$ A. G. Hilliard, "Kermetic Concepts In Education" in Nile Valley Civilization (ed) Ivan Van Sertima, 1985 p157. The greatest of the Egyptian temples where the Mystery schools existed was called 1 pet-Isut e.e. "the most secret of places" according to 
Hilliard ibidem and in the view of Abdulahi, it had over 80,000 students at all grades at one time like other centre of learning, ipet-isut had a library and a faculty.

"Ibiden. Also, ancient Egyptian philosophy and sciences were taught without much external interference from 50000 B.C. until the invasion and sack of Egypt by Alexander in 332 BC". Cfr Francis Ogunmodede, "Philosophy in Ancient African in

West African Journal of Ecclesial Studies Ibadan: Aecawa Publications Vol. 4 1999 P141

${ }^{15} \mathrm{Cfr}$. Martin Bernal, Black Athena; The Afroasiatic Roots of Classical Civilization. Vol II, Rutgers University Press, New Jersey, 1991 ${ }^{16} \mathrm{Sir}$ Isaac Newton(1642-1727 ) the great Engish physicist said also inter alia of the Egyptian origin of philosophy thus:

The Egyptians were early observers of the heave: and from them, probably this [philosophy spread among other nations: for from them that it was and the nations about them that the greeks, a people more addicted to the study of philosophy(i.e.language translation, etc) than of Nature derived first as well as their soundest notions of philosophy, and in the vestal (ie.secredt and sacred ceremonies we may yet trace the ancient spirit of the Egyptian, for it was their way to dekiver their mysteries, that is their philosophy of things, about the common way of thinking, under then vell of religious rites and hieroglyphic symbols. (quoted in Joseph Osei, "Who Were the First Philosophers Ancient Greeks or Black African?" in Legon Journal of the Humanities, Vol viii. 1995p.30)

Plato told the story of how mathematics came about to his students;

The story is that in the region of Naucratis in Egypt there dwelt one of the old gods of the country, the god to whom the bird called Ibis is sacred, his own name being Theuth. He it was that invented number and calculation, geometry and astronomy, not to speak of draughts and dice, and above all writing (Plato, Phradeus, $274 \mathrm{C}-d$. Translation from the collected Dialogues by Edith Hamilton and Huntington Cains, Princeton University Press, New Jersey, 1961)

Isocrates, a contemporary of Plato, also, refers to Egypt as the origin of philosophy instead of Greece thus:

I am not the only man or the first to have observed the piety of the Egyptians, any, both now and in the past have done so including Pythagoras of Samos, who went to Egypt and studied with the Egyptians. He was the first to bring philosophy to Greece.(Herodotus $I I, 109$ Ibid) 
On the part of Aristole, Philosophy first began in Egypt among the priestly caste who had the time for leisure and speculation;

When all such (interventions related to the necessity of life and art)were established, the sciences which do not aim at giving (physical) pleasure or at the necessities of the life were discovered, and first in the places where men first began to have leisure. This is why the mathematical art(science of precise knowledge or philosophy) were founded in Egypt; for there the priestly caste was allowed top be at leisure. [Aristotle Metaphysics (9816, 20-24) translated by Richard Mckeon Newyork: Random House; 1941]. 17 It is definite that the Greek thinkers and philosophers were not dumb and had made their own additions and contributions to what they obtained from the Egyptians. They did this according to the needs of their own mileu and city states e.g. individualism in contrast to Egyptian wholism and collectivism. ${ }^{18}$ J. Eneh op.cit. p.56

${ }^{19}$ A.G. Hilliard, op. cit. p157

${ }^{20}$ M.K. Asante op. cit p.vii

${ }^{21}$ Ibidem p. xiii

${ }^{22}$ Ibidem p. xiii

${ }^{23}$ Ashante op cit. xiv

${ }^{24}$ Ibidem

${ }^{25}$ Ibidem

${ }^{26}$ Ibidem

${ }^{27}$ Ibidem

${ }^{28}$ Ashante op.ci XV

${ }^{29}$ Ibidem

${ }^{30}$ Ibidem

${ }^{31}$ Ashante op cit. $x v-x v i$

${ }^{32}$ G. James, op.cit p10

${ }^{33}$ Ibidem

${ }^{34}$ J. Eneh, op. cit pp86-94

${ }^{35}$ Ibidem p 93

${ }^{36}$ Ibidem_p 94

${ }^{37}$ Ibidem, 90

38 The punic wars were fought $261-241 B C ; 218-201 B C$; and $149-146 B C$.

39 J.Eneh op.cit p.75

${ }^{40} \mathrm{Cfr}$.C. Sumner, "Ethiopia: Land of Diverse Expressions of philosophy; Birth place of Modern thoughts" in African philosophy, Addis Ababa, 1976, 225. 
${ }^{41}$ Cfr. J.K.Zerbo (ed); Methodology in and African Pre-History, Unesco Publication, 1985.

42 G.E. Azenabor op.cit pp1-17

43 J.E. Wiredu Philosophy and an African Culture, London: Cambrige University Press, 1980, p.27.

44 P. O. Bodunrin, Trends and Perspective In African Philosophy. University Press, 1985, p.xi

45 O. Oladipo, The Idea Of African Philosophy Ibadan: Molecular Publishers, 1992 , p.28

${ }^{46} \mathrm{Cfr}$ K.C.Anyanwu, The Atomistic And Holistic Philosophers:A Strife Between The Analytic And Metaphysical Modes of Thoughts, California North Folk: Heartland Publishers, 1982.

47 G. Sogolo, Foundations Of African Philosophy: A Definitive Analysis of Conceptual Issues In African thought, Ibadan: University Press, 1993, p.5 ${ }_{48}$ O. Oruka, Trends In Contemporary African Philosophy; Nairobi: Shirikon Publishers, 1990

49 _ Sage Philosophy: Indigenous Thinkers and Modern Debate On African Philosophy, Nairobi: Africaan Center for Technology Studies, 1991) Jay Van Hook,

"African Philosophy: Its Quest For Identity" in Quest Philosophical Discussions, Vol Vii, No I, June, 1993.

${ }^{50}$ Cfr. Jay Van Hook, "African Philosophy: Its Quest For Identity" in Quest Philosophical Discussions, Vol Vii, No I, June, 1993.

${ }_{51}$ A.F. Uduigwomen, Footmarks On African Philosophy, Lagos: Obaroh and Ogbinaka Publishers, 1995 pp4-6.

52 M.F. Dukor, Theistic Humanism: Philosophy Of Scientific Humanism, Lagos: Chumah and sons Productions, 1994

${ }^{2}$ C.S. Momoh, Issues In African Philosophy; The Substance Of African

Philosophy, Op.cit pp51-87.

${ }^{54}$ G.E. Azenabor, op.cit p 14.

55T.U Nwala,Amo

's place in Intellectual History

, Nsukka, 1990. p.3

56

,The Great Debate On African Philosophy (1970-1990),

Nsukka: University Of Nigeria, 1992, p4

${ }^{57} \mathrm{Cfr}$. Marcel Griaule, Conversaations With Ogothomeli: An Introduction to Dogon Religious Ideas, London: Oxford University Press, 1965.

${ }^{58}$ C.S. Momoh, op.cit p 51.

59M.A Makinde,"Philosophy In Africa" in C.S Momoh(ed)The Substance of African Philosophy op.cit.

60 Mary Lefkowitz, Not Out Of Africa: New York: Basic Books, 1996 pp88125. 
${ }^{61}$ Cfr. F.Ogunmodede,

"African Philosophy In African Language

", West African Journal Of Philosophical Studies, Vol I, No 1, September 199 pp 13-15.

${ }^{62} \mathrm{Cfr}$.

"Philosophy in Ancient Africa", West African Journal Of Ecclesia studies, Vol 14, 1998 pp 132-145; "Philosophy Re-Examines Its Ancient Origin, ", West African Journal Of Philosophical Studies Vol. 3 December 2000 p.27 Also,

Of History and Historiography in African Philosophy, Ibadan: Hope Publications 2001, pp 1-45. 